University of Nebraska - Lincoln

DigitalCommons@University of Nebraska - Lincoln

USDA Wildlife Services - Staff Publications

U.S. Department of Agriculture: Animal and Plant Health Inspection Service

November 2001

\title{
Differential responses of coyotes to novel stimuli in familiar and unfamiliar settings
}

Charles E. Harris

Frederick F. Knowlton

Follow this and additional works at: https://digitalcommons.unl.edu/icwdm_usdanwrc

Part of the Environmental Sciences Commons

Harris, Charles E. and Knowlton, Frederick F., "Differential responses of coyotes to novel stimuli in familiar and unfamiliar settings" (2001). USDA Wildlife Services - Staff Publications. 533.

https://digitalcommons.unl.edu/icwdm_usdanwrc/533

This Article is brought to you for free and open access by the U.S. Department of Agriculture: Animal and Plant Health Inspection Service at DigitalCommons@University of Nebraska - Lincoln. It has been accepted for inclusion in USDA Wildlife Services - Staff Publications by an authorized administrator of DigitalCommons@University of Nebraska - Lincoln. 


\title{
Differential responses of coyotes to novel stimuli in familiar and unfamiliar settings
}

\author{
Charles E. Harris and Frederick F. Knowlton
}

\begin{abstract}
We studied behavioral responses of captive and wild coyotes (Canis latrans) toward novel objects and artificial scent stations to determine how they might respond to novel stimuli used in coyote management and research. When captive coyotes encountered novel stimuli in unfamiliar surroundings they showed little avoidance, while the same stimuli caused avoidance and neophobic reactions among coyotes when encountered in familiar surroundings. In the field phase of the study, radio-collared coyotes in southern Texas were intensively monitored in order to relate space-use patterns to the locations where these coyotes were exposed to artificial scent stations. Coyotes were more likely to respond to and score (record visits by leaving tracks) at artificial scent stations when these were encountered outside or on the periphery of their home areas than when they were encountered within their home area. This suggests that indices of coyote abundance that employ responses to novel situations may more readily record coyotes that are outside the central portions of their home areas and that transient or dispersing coyotes are more likely to be "counted" than residents.

Résumé : Nous avons étudié le comportement du Coyote (Canis latrans) en présence d'objets nouveaux ou de sites d'odeurs artificielles, en nature et en captivité, dans le but de déterminer comment cet animal réagira face à des stimulus nouveaux présentés dans le cadre de recherches ou de programmes d'aménagement. En présence de stimulus nouveaux dans un environnement non familier, les coyotes en captivité ne réagissent pas, alors que les mêmes stimulus déclenchent des comportements d'évitement et des réactions néophobes en milieu familier. En nature, nous avons suivi de près des coyotes du sud du Texas porteurs de colliers émetteurs-radio dans le but de comparer les patterns d'utilisation de l'espace en fonction des endroits où ces coyotes ont été mis en présence de sources d'odeurs artificielles. Les coyotes étaient plus enclins à réagir aux sources d'odeurs et à les marquer (laissant des traces de leur passage) en périphérie et en dehors de leur domaine qu'à l'intérieur. Les coefficients d'abondance basés sur les réactions à de nouvelles situations risquent donc d'accorder plus d'importance aux coyotes qui se trouvent à l'extérieur de la partie centrale de leur domaine, ce qui laisse entrevoir la possibilité que les coyotes de passage ou en phase de dispersion aient plus de chances d'être comptés que les résidants.
\end{abstract}

[Traduit par la Rédaction]

\section{Introduction}

Although many coyote (Canis latrans) management and research techniques rely on behavioral responses, we know relatively little about the basic psychological patterns that influence coyote reactions to such techniques (Lehner 1976). Coyote movement patterns and space utilization have been extensively studied, but limited mostly to estimates of homerange size and relationships among occupants of adjacent territories (Laundre and Keller 1984; Windberg and Knowlton 1988; Gese and Ruff 1997; Kitchen et al. 2000). Home ranges provide animals with the resources for growth, maintenance, and reproduction. They also provide a familiar environment within which animals can acquire a detailed knowledge of

Received May 2, 2001. Accepted September 7, 2001.

Published on the NRC Research Press Web site at http://cjz.nrc.ca on November 9, 2001.

C.E. Harris. ${ }^{1}$ Department of Fisheries and Wildlife, Utah State University, Logan, UT 84322-5210, U.S.A.

F.F. Knowlton. ${ }^{2}$ National Wildlife Research Center, Utah State University, Logan, UT 84322-5295, U.S.A.

${ }^{1}$ Present address: Wildlife Bureau, Idaho Department of Fish and Game, P.O. Box 25, Boise, ID 83707, U.S.A.

${ }^{2}$ Corresponding author (e-mail: knowlton@cc.usu.edu). the nature and spatial relationships of objects, resources, pathways, and potential dangers. Familiarity is maintained through frequent exposure, with change detected by deviations from the familiar and by recognition of, and response to, novel stimuli (Sheppe 1966). Animals commonly fear or avoid novel stimuli when in familiar environments, yet the same stimuli frequently elicit inquisitive responses when encountered in unfamiliar environments, where most stimuli are novel (Barnett 1958b; Cowan 1976, 1977). Windberg (1996) demonstrated that these concepts also apply to coyotes, the degree of response being linked to the intensity of the stimulus.

Small mammals appear to be more vulnerable to predation in unfamiliar than in familiar environments (Errington 1946, 1967; Barnett 1963; Metzgar 1967). Coyotes and wolves (Canis lupus) also appear to be more vulnerable to trapping and man-induced mortality in areas that are less familiar to them (Mech 1977; Althoff 1978; Litvaitis 1978; Woodruff and Keller 1982). Hibler (1977) suggested that coyotes were more commonly trapped along the periphery of and outside their home areas than inside, although coyotes spend relatively little time outside their home areas. Windberg and Knowlton $(1988,1990)$ provide a more graphic analysis in which only 2 of 26 territorial female coyotes (8\%) were trapped within the area where they spent over $60 \%$ of their 
time and 18 were captured on the periphery or outside their territory. In addition, they reported that 9 of 12 nonterritorial females $(75 \%)$ were trapped outside their more familiar environments. These interpretations were reinforced by the results of a later study by Windberg et al. (1997).

Although Balph (1968) emphasized the importance of considering species' behavior when various population estimators are used, the potential effect of behavioral changes on the biases associated with research and management techniques is seldom addressed. The increased vulnerability of coyotes to trapping when away from their primary areas of activity leads to speculation about biases in the use of trapped animals for estimating population parameters, as well as in the use of artificial scent stations (Linhart and Knowlton 1975; Roughton and Sweeney 1982) for determining the relative abundance of carnivores. Lehner (1976) raised several behavioral questions regarding the scent station survey technique used for assessing coyote abundance, including placement of scent-station lines with regard to the sociospatial distribution of coyotes and whether lines along territorial boundaries might produce more visitations than those through the middle. Herein we attempt to $(i)$ assess the types and ranges of behavioral responses of captive coyotes toward novel stimuli, including artificial scent stations, in both familiar and unfamiliar environments, and (ii) provide a basis for interpreting the responses of free-ranging coyotes to artificial scent stations in relation to home-area boundaries.

\section{Methods}

Our study was conducted in two phases. We started by comparing responses of captive coyotes to novel stimuli, including novel objects and artificial scent stations, in both familiar and unfamiliar settings (pens). The other phase of the study examined responses of free-ranging coyotes in southern Texas to artificial scent stations encountered within and outside their home areas.

\section{Responses of captive coyotes}

\section{Location}

Reactions of captive coyotes were assessed at the Predator Ecology and Behavior Project research facility $8 \mathrm{~km}$ south of Logan, Utah. Two adjacent 1-ha wedge-shaped enclosures of the "Pi Pen" complex composed the experimental enclosures for this phase of the study. Each enclosure radiated $160 \mathrm{~m}$ from a central elevated observation building to an outer arc $125 \mathrm{~m}$ in length. Vegetative cover was a grass-alfalfa mixture. Color-coded steel stakes were used in a polar coordinate system to create a grid within each enclosure to aid in identifying coyote locations. Experimental animals were housed in kennels that were located beneath the observation building and opened into their respective experimental arenas. A wooden wall prevented coyotes from viewing activities in the pens while they were in the kennels.

\section{Subjects}

Eleven captive coyotes at least 18 months of age and naive to the experimental enclosures were used to study coyote responses to novel objects. All had been born in captivity; 6 had been handreared and 5 were parent-reared. Twenty-two other captive coyotes at least 12 months of age and naive to the pen complex were used to study coyote responses to scent stations. These also had all been born in captivity but none was hand-reared. Hand-reared coyotes had been removed from their mothers at approximately 10 days of age and bottle-fed a milk-replacer formula for 4-6 weeks and then weaned to a solid-food diet. Litters of both hand-reared and parentreared pups were kept intact in vegetated 0.1-ha pens with access to water, den boxes, and shade. Litters were in visual contact with other coyote litters in adjacent pens and could hear adults, other pups, and wild coyotes in the area. When they were 36-40 weeks of age, littermates were moved to individual kennels but were still in visual, auditory, and olfactory contact with each other and with other coyotes.

\section{Experiments with novel objects}

An experimental trial was conducted with 1 coyote per pen for a 17-day period, with two trials conducted concurrently in adjacent pens. We placed each coyote in a holding kennel and gave it 3 days to acclimate to the kennel. To test responses to novel objects in an unfamiliar environment, on the evening of day 3 we placed a novel object, either a black cube or a black pyramid $(15 \mathrm{~cm}$ on a side) in a randomly chosen sector of the 1-ha pen. The next morning the coyote was given access to the pen and we recorded behavioral observations for $8 \mathrm{~h}$, including location and activity at 1-min intervals. On days $6,8,10,12,14$, and 16 we recorded $2-4 \mathrm{~h}$ of additional observations. After observations were completed on day 16 (i.e., after 13 days of familiarization with the pen), the coyote was sequestered in its kennel and an alternative novel object, different from the initial object, was placed in a sector of the pen frequently used by the coyote. On the morning of day 17 the coyote was again released into the pen and observations were conducted as before to assess coyote responses to a novel object in a familiar environment. Coyote behaviors directed toward the novel objects were recorded on videotape.

\section{Experiments with scent stations}

Responses to scent stations in an unfamiliar environment were determined by individually testing each of 8 coyotes ( 4 males and 4 females) that had not been used in the novel-object tests. After a coyote had been allowed to acclimate to the kennel for 3 days, it was released into the adjoining 1-ha pen containing a single artificial scent station (Linhart and Knowlton 1975; Roughton and Sweeny 1982) that had been prepared in a randomly selected sector of the pen the previous evening. The scent station consisted of a circular area $1 \mathrm{~m}$ in diameter cleared of vegetation and smoothed. A fine layer of dust was sifted onto the surface to facilitate reading coyote tracks. The next morning a small perforated plastic capsule containing $1 \mathrm{~g}$ of fatty acid scent (FAS) attractant (Roughton 1982) was placed in the center of the cleared area and supported 1.0$3.0 \mathrm{~cm}$ above the surface by a small stick. The coyote was released from the kennel $1 \mathrm{~h}$ later and observations and data were recorded as described under the novel-object tests.

We assessed coyote responses to scent stations in familiar environments by allowing each of 14 coyotes ( 7 males and 7 females) not used in earlier portions of the study access to a 1-ha pen for a 10-day familiarization period. On the evening of day 10 the coyote was restricted to its kennel and a scent station was prepared in a sector of the pen frequently used by the coyote during the familiarization period. A scent capsule was placed in the cleared area on the morning of day 11 and the coyote was released into the pen $1 \mathrm{~h}$ later and observations started. Data were recorded as described previously.

\section{Behavioral analyses}

We evaluated coyote responses to the novel objects and scent stations via detailed analyses of the videotaped sequences. We counted the approaches coyotes made to the novel stimuli, determined the amount of time they spent within $5 \mathrm{~m}$, and categorized their behavioral responses as nonavoidance, caution, or neophobia. Nonavoidance behaviors included a direct approach and close $(<1 \mathrm{~m})$ visual and olfactory examination. Some coyotes exhibited a "cautious demeanor" characterized by approaching the object or scent 
station directly but slowly, and when within 1-2 m, stretching forward for visual and olfactory inspection. They seldom circled the object or showed any approach-withdrawal behaviors. The neophobic or avoidance category of response included circling, approachwithdrawal behaviors, visual and olfactory assessment of the situation from a distance $(>5 \mathrm{~m})$, or avoidance of the vicinity $(<10 \mathrm{~m})$ of the novel object or scent station after initial detection. In many cases the coyotes in this category displayed obvious interest and curiosity but conducted their inquest from a distance, returning repeatedly to the novel stimulus for additional examination but deferring close $(<1 \mathrm{~m})$ inspection of the object or scent station.

Differences in frequencies of avoidance and nonavoidance behaviors in familiar and unfamiliar environments were tested using Fisher's exact test (Zar 1996). Differences in frequencies of approach and the time spent within $5 \mathrm{~m}$ of the object were assessed with a Mann-Whitney test (Zar 1996) or Wilcoxon's signed-rank test (Hollander and Wolfe 1973).

\section{Responses of wild coyotes}

We conducted a field study to verify whether the results obtained in the pen studies were applicable to field situations by using telemetered coyotes and scent-station visits.

\section{Study area}

The study area encompassed about $250 \mathrm{~km}^{2}$ of the Clinton Manges ranch approximately $10 \mathrm{~km}$ southwest of Freer in Duval and Webb counties, Texas. The topography of the ranch was level to rolling and classified in the South Texas Plains vegetational area (Gould 1975). The vegetative communities were composed primarily of dense stands of woody shrubs dominated by honey mesquite (Prosopis glandulosa), blackbrush acacia (Acacia rigidula), and Texas prickly pear (Opuntia lindheimeri). The climate of the region is semi-arid, with erratic precipitation among and within years; mean annual precipitation is $45 \mathrm{~cm}$. Mean monthly temperatures for Laredo, $80 \mathrm{~km}$ southwest of the study area, are $8^{\circ} \mathrm{C}$ in January and $38^{\circ} \mathrm{C}$ in July (U.S. Department of Commerce 1982).

\section{Procedures}

We used a helicopter to search areas near fixed-location radiotracking shelters for coyotes. When coyotes were located, we tranquilized them from the air with darts containing a combination of ketamine hydrochloride and xylazine (Baer et al. 1978; Cornely 1979). We attempted to dart only adult coyotes because we considered them more likely to have well-established home ranges and to be less likely to disperse. We fitted each captured coyote with a radio transmitter (Kolz et al. 1973) and amputated a single toe (Andelt and Gipson 1980) from a forefoot to enable individual track recognition at scent stations. We recorded the sex, body mass, general physical condition, capture location, and estimated age based upon tooth wear. Animals less than 1 year old were classified as juveniles and all others as adults. We also extracted a lower premolar for verifying age by means of radiographs and (or) cementum annuli analysis (Linhart and Knowlton 1967; Knowlton and Whittemore 2001). We held the animals overnight to allow recovery from the capture drugs and then released them at their respective capture sites.

Radio-collared coyotes were monitored from fixed-station tracking shelters equipped with two 5-element Yagi antennas stacked horizontally and coupled out of phase with a sum and difference hybrid junction (Knowlton 1995). Antenna orientation was established and maintained with a beacon transmitter placed at a known location. The baseline between the tracking shelters was $5.75 \mathrm{~km}$.

We used standard triangulation techniques (Heezen and Tester 1967), using simultaneous azimuths from the two radio-tracking shelters, to estimate sequential locations of each animal and excluded all locations based on azimuths that intersected at angles $<20^{\circ}$ or $>160^{\circ}$ to avoid gross misrepresentation of coyote locations
(Knowlton 1995). Our sampling at 15-min intervals between 16:00 and 08:00 provided a detailed assessment of the movement patterns of radio-collared coyotes within a relatively short time period. Space-utilization analyses were done with HOMER (Rongstad and Tester 1969) and a SPSS cross-tabs program (Nie et al. 1975) that overlaid the study area base maps with 0.25 - or $0.01-\mathrm{km}^{2}$ grids to depict the number of locations and percentage of total locations within each of these grid cells (Rongstad and Tester 1969; Laundre and Keller 1981).

After a 2- to 3-week monitoring period to assess coyotes' spaceutilization patterns and home areas, we established a series of modified scent station survey lines (Linhart and Knowlton 1967; Roughton and Sweeny 1982). Logistical limitations forced us to run scent stations in half the study area for one 10-day period and in the other half of the area for the succeeding 10 days. We checked the scent stations daily for tracks of marked and unmarked coyotes and monitored coyote movement patterns throughout this period. All scent capsules were replaced midway through each 10day survey period.

Hibler (1977) defined a peripheral zone as a $0.5-\mathrm{km}$ area on either side of a home-range boundary. In our study, both quantitative and qualitative characteristics were used to define the home area, a peripheral zone, and areas outside the peripheral zone. The variables we used were the percentage of total relocations within a specific grid cell and the relative position of each grid cell with respect to known adjacent coyote home areas or to physical features acting as potential boundaries between adjacent coyote home areas (primarily roads), or both. Grid cells containing $<0.5 \%$ of total relocations were considered to be outside the peripheral zone, cells containing $0.6-1.5 \%$ of total relocations were considered to be within the peripheral zone, and cells containing $>1.5 \%$ of locations were identified as being part of the home area (inside the peripheral zone). Adjustments were sometimes made between outside and peripheral designations depending on the position of the grid cell with respect to the rest of the home area.

Differences in numbers of visits among scent stations placed inside the home area, within the peripheral zone, and outside the peripheral zone of the respective coyote home areas were tested with a Mann-Whitney test (Zar 1996) or Wilcoxon's signed-rank test (Hollander and Wolfe 1973).

\section{Results}

\section{Captive coyotes}

We did not detect any difference in the behaviors of handreared and parent-reared coyotes with respect to either the amount of time spent within $5 \mathrm{~m}$ or the number of approaches to novel objects in either the familiar or the unfamiliar environment $(U=19.0-26.0, P>0.05)$. Accordingly, we disregarded rearing history in subsequent analyses.

Despite relatively large discrepancies in sample means, in 6 of 8 statistical tests comparing responses of males and females, no differences were detected $(U=9.5-28.0, P>0.20$, largely as a result of wide variances in responses within classes (Tables 1 and 2). The other 2 tests indicated that males spent a greater amount of time within $5 \mathrm{~m}(Z=2.556$, $P<0.01)$ and made more approaches $(Z=2.647, P<0.01)$ to the novel objects encountered in a familiar environment than in an unfamiliar environment (Table 2). In subsequent analyses we combined samples of males and females.

Our samples (cell frequencies) were too small to utilize contingency-table analysis with 3 behavioral-response categories within the familiar and unfamiliar settings (Zar 1996). Hence, we combined the categories caution and neophobia. 
Table 1. Responses of captive coyotes to novel objects encountered within familiar and unfamiliar environments (pens).

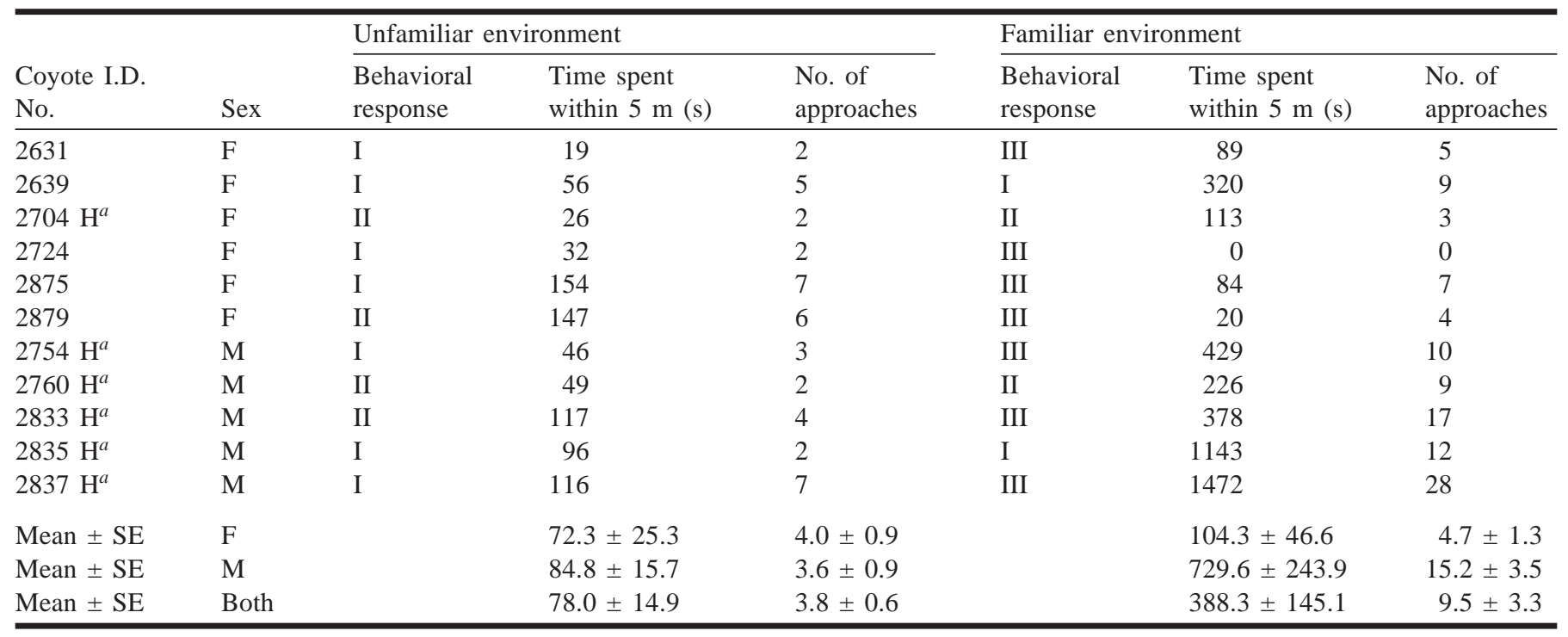

Note: Behavioral response are as follows: I, nonavoidance; II, caution; III, neophobia.

${ }^{a}$ Hand-reared.

Table 2. Responses of captive coyotes to scent stations when encountered in familiar and unfamiliar environments (pens).

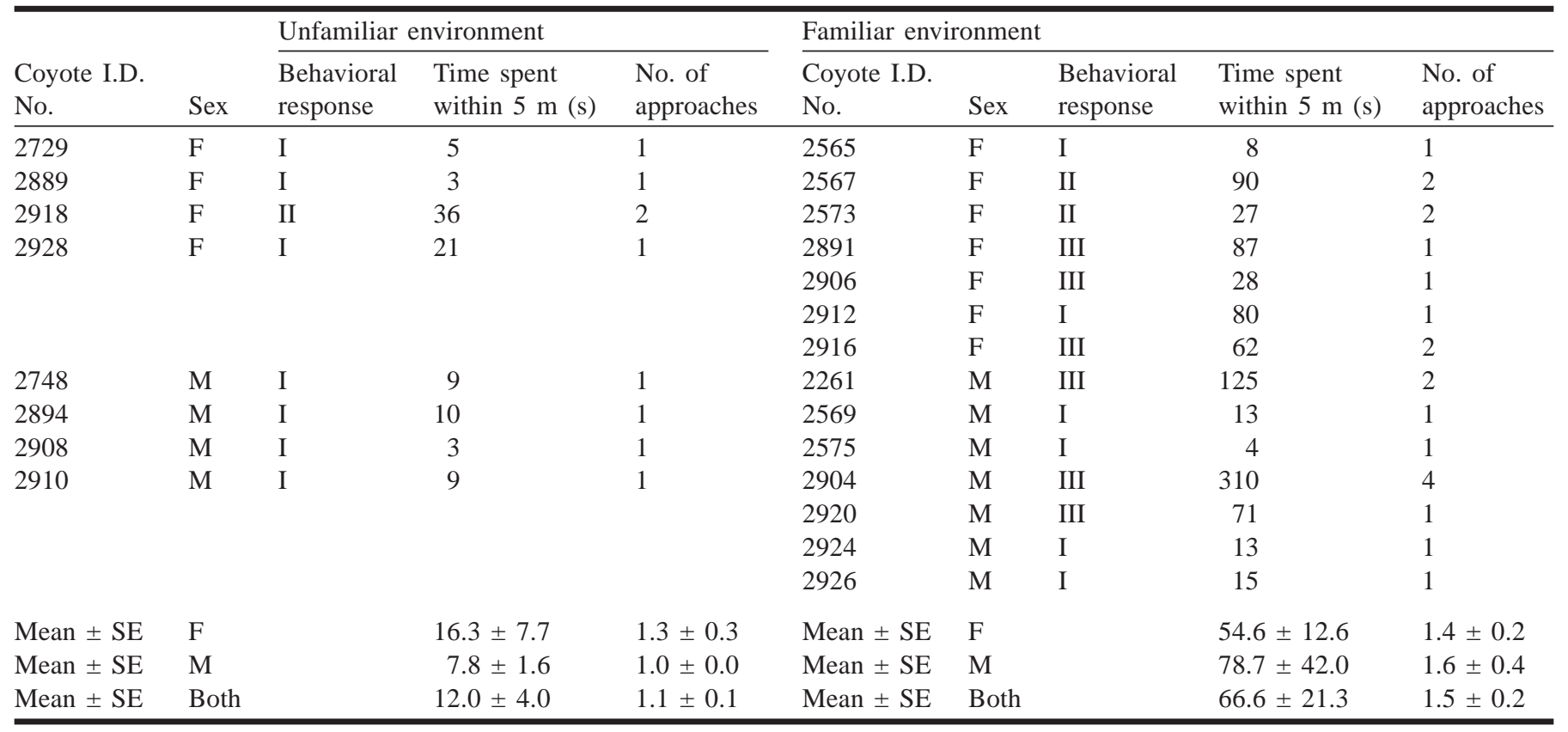

Note: Behavioral response are as follows: I, nonavoidance; II, caution; III, neophobia.

Nine of 11 captive coyotes responded in a cautious/neophobic manner to the novel objects encountered in a familiar environment, whereas only 4 of 11 coyotes did so in an unfamiliar environment (Table 1; Fisher's exact test, $P=0.04$ ). Despite the coyotes' cautious/neophobic reactions, in the familiar environment the novel objects elicited more investigative time (time spent within $5 \mathrm{~m}$ ) (Wilcoxon's paired tests, $Z=2.178, P=0.01)$ and more approaches $(Z=2.293, P=$ 0.01 ) than in the unfamiliar environment (Table 1).

In the scent-station phase of the study, 7 of 8 coyotes readily approached and scored (stepped onto the scent station) when they encountered it in the unfamiliar environment
(Table 2). Although 8 of 14 coyotes scored at the scent stations on their first approach in the familiar environment, only 2 readily approached the stations, 6 paused or circled in their first approach to the station before scoring (Table 2), and 4 others scored upon returning to the scent stations during a subsequent approach. Again, cell frequencies were too small for $\chi^{2}$ analysis, so we combined the behavioral categories caution and neophobia. Differences between the behavioral categories caution/neophobia and nonavoidance in the familiar and unfamiliar environments were significant (Fisher's exact test, $P<0.05)$. Coyotes spent more time investigating the scent stations in the familiar environment than in the 
Table 3. Number and percentage of telemetry locations, day of visit, and home-range zone of scent-station grid cells visited by marked coyotes in Duval County, Texas, 1980.

\begin{tabular}{|c|c|c|c|c|c|}
\hline \multirow{2}{*}{$\begin{array}{l}\text { Coyote I.D. } \\
\text { No. }\end{array}$} & \multirow[b]{2}{*}{ Visit No. } & \multicolumn{2}{|c|}{ Visited grid cell } & \multicolumn{2}{|c|}{$\begin{array}{l}\text { Telemetry locations } \\
\text { within grid cell }{ }^{a}\end{array}$} \\
\hline & & Location $^{b}$ & Day of visit & No. & $\%$ of total ${ }^{c}$ \\
\hline \multirow[t]{2}{*}{01} & 1 & Outside & 11 & 2 & 0.2 \\
\hline & 2 & Inside & 13 & 89 & 7.4 \\
\hline \multirow[t]{2}{*}{03} & 1 & Periphery & 8 & 2 & 0.2 \\
\hline & 2 & Periphery & 9 & 4 & 0.3 \\
\hline \multirow[t]{2}{*}{07} & 1 & Periphery & 5 & 1 & 0.1 \\
\hline & 2 & Periphery & 9 & 4 & 0.5 \\
\hline \multirow[t]{4}{*}{08} & 1 & Periphery & 3 & 9 & 0.8 \\
\hline & 2 & Periphery & 5 & 4 & 0.3 \\
\hline & 3 & Periphery & 12 & 7 & 0.6 \\
\hline & 4 & Periphery & 13 & 2 & 0.2 \\
\hline \multirow[t]{5}{*}{09} & 1 & Periphery & 1 & 1 & 0.1 \\
\hline & 2 & Inside & 7 & 37 & 2.9 \\
\hline & 3 & Outside & 14 & 1 & 0.1 \\
\hline & 4 & Outside & 14 & 1 & 0.1 \\
\hline & 5 & Outside & 16 & 1 & 0.1 \\
\hline \multirow[t]{3}{*}{10} & 1 & Outside & 7 & 1 & 0.1 \\
\hline & 2 & Outside & 7 & 1 & 0.1 \\
\hline & 3 & Periphery & 10 & 19 & 1.6 \\
\hline 11 & 1 & Periphery & 8 & 4 & 0.3 \\
\hline \multirow[t]{4}{*}{12} & 1 & Peripheral & 2 & 12 & 1.0 \\
\hline & 2 & Outside & 3 & 1 & 0.1 \\
\hline & 3 & Periphery & 8 & 12 & 1.0 \\
\hline & 4 & Periphery & 10 & 8 & 0.6 \\
\hline
\end{tabular}

\footnotetext{
${ }^{a}$ Telemetry locations of the coyote within the grid cell in which it visited a scent station.

${ }^{b}$ Designation with regard to home-area boundary.

${ }^{c}$ Percentage of the total number of telemetry locations for that coyote.
}

unfamiliar environment (Mann-Whitney test, $Z=2.525, P<$ 0.01 ), but no difference in the numbers of approaches to the scent stations was detected $(Z=0.921, P=0.12$, Table 2$)$.

When the coyotes were in unfamiliar surroundings, novel objects elicited more attention than scent stations, as was shown by a significantly greater amount of time spent within $5 \mathrm{~m}$ (Mann-Whitney test, $Z=3.303, P<0.01$ ) and more approaches $(Z=3.427, P<0.01)$. Results were similar when these two types of stimuli were encountered in the familiar environment, with more time spent within $5 \mathrm{~m}$ of the novel objects (Mann-Whitney test, $Z=2.409, P<0.01$ ) and more approaches made $(Z=3.367, P<0.01)$. Although quantitatively different, responses to the two types of novel stimuli were qualitatively similar, responses to the scent stations being less intense than those elicited by the novel objects.

\section{Wild coyotes}

We captured, radio-collared, and monitored 9 coyotes in the field portion of the study. The home areas of these coyotes were based upon 551-672 radiolocations each $($ mean = 628) made between 21 February and 6 March 1980 . We excluded about $30 \%$ of the locations from 2 coyotes because their home areas lay along the baseline of the tracking shelters, where radio azimuths intersected at extremely acute or obtuse angles $\left(<20^{\circ}\right.$ or $\left.>160^{\circ}\right)$.

During 2345 scent-station-nights conducted between 19 March and 10 April, we recorded 462 coyote visits to scent stations, 23 by marked animals (Table 3 ). Tracks of 8 of the 9 marked coyotes were recognized at scent stations. Twentyone of the 23 visits by these coyotes were either peripheral to or outside their respective home areas, including all of the initial visits to scent stations (Table 3).

The relatively small size of coyote home areas in southern Texas, coupled with our use of $0.5 \mathrm{~km}$ wide peripheral zones, resulted in only 6 scent stations meeting the criteria for being inside coyote home areas. The frequencies with which coyote telemetry locations were in grid cells with visited and nonvisited scent stations were similar $\left(\chi_{[2]}^{2}=0.724, P=\right.$ $0.70)$. This suggests that scent station survey lines were not biased with respect to the manner in which coyotes used their home areas, i.e., the 3 home-area zones were representatively sampled, given the roads available for scent station survey lines. Because the frequency of use of grid cells as small as $0.01 \mathrm{~km}^{2}$ could be influenced by minor errors in the telemetry system, a mean frequency of use was also calculated that included the eight grid cells immediately adjacent to the grid cell containing the scent station. The frequency of coyote use of grid cells with visited scent stations was again similar to the frequency of use of grid cells with nonvisited scent stations $(W=0.69, P<0.48)$.

The percentage of total relocations in grid cells with visited scent stations in peripheral zones versus inside (MannWhitney test, $U=28, P<0.02)$ or outside the peripheral zones $(U=89, P<0.01)$ was significant. Differences between 
Table 4. Comparison of the numbers of telemetry locations in grid cells with scent stations in relation to home-area boundaries of marked coyotes.

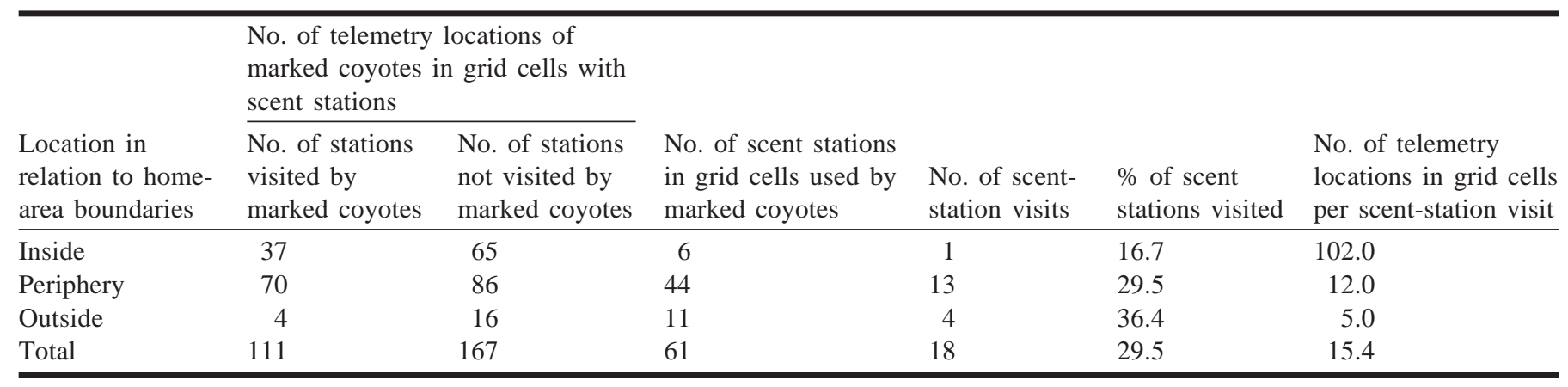

the outside and inside zones were not significant $(U=14$, $P=0.10$ ), probably reflecting the small samples in each area.

A greater proportion of scent stations peripheral to and outside the home area than inside were visited $\left(\chi_{[2]}^{2}=5.469\right.$, $P<0.065$ ), suggesting differential detectability, differential behavior, or both by coyotes toward scent stations when in zones that differed with respect to to their home areas. The ratio of the number of telemetry relocations in grid cells with visited scent stations per scent-station visit also suggests differential behavior (Table 4), with coyotes apparently requiring greater exposure to (i.e., familiarity with) scent stations inside their home area than either within or outside the peripheral zone before they "track" the scent stations. Although these data are meager, they suggest that coyotes may be as much as 20 times more likely to visit a scent station detected outside their home area than one detected inside their home area. The single scent-station visit by a marked coyote inside its home area was confounded because that coyote had visited a peripheral scent station 2 days previously.

The paucity of scent stations in core areas of coyote home ranges was related to the fact that coyote home ranges in this study were relatively small $\left(\right.$ mean $=2.70 \mathrm{~km}^{2}, \mathrm{SE}=0.35 \mathrm{~km}^{2}$ ), which, combined with a high percentage of roads comprising home-range boundaries, resulted in relatively few roads within the core areas. In addition, since spacing between scent stations remained constant $(0.48 \mathrm{~km})$, few were accommodated within the core of small home ranges.

\section{Discussion}

The results of our studies corroborate those of Windberg (1996), indicating that captive coyotes readily investigate novel objects encountered in unfamiliar environments but are generally less inclined to do so when the same novel objects are encountered in familiar environments. The responses of our captive coyotes to artificial scent stations in familiar and unfamiliar surroundings were similar to their responses to novel objects, although avoidance of scent stations did not appear to be as intense as avoidance of novel objects. The results from our field tests with artificial scent stations are consistent with those from our pen tests.

Different stimuli may arouse animals to different levels, depending upon the properties of the stimuli and prior experiences of the animal. Strong or discrepant stimuli may cause withdrawal, whereas weak stimuli may elicit approach (Schneirla 1965). Although Windberg (1996) detected no difference between black and white novel objects, he noted a difference in the degree of neophobia associated with the size of novel objects, with larger objects more frequently eliciting caution than smaller ones. Novelty appears to set up a dynamic tension between curiosity and anxiety, with strong or unusual stimuli perceived as potentially threatening, whereas unusual and mild stimuli invite exploration. This would be consistent with the prey-choice model of Ruggiero et al. (1979) in which American kestrels (Falco sparverius) selected novel prey over normal prey when the perceived threat was low (non-movement) but reversed their choice when prey movements increased the intensity of the perceived threat. In our and Windberg's (1996) studies, coyotes may have recognized changes in familiar environments (insertion of new objects) as a potential threat, the degree of threat being related to the degree of discrepancy (object size) associated with the stimulus. When coyotes were in unfamiliar surroundings, novel situations were not recognized because everything was novel and any anxiety would have been diffused across a multitude of objects in the environment.

The neophobic reactions of our captive coyotes to novel items in familiar environments probably should be interpreted as representing not disinterest or fear but, rather, distrust and caution. Our captive coyotes approached novel situations more often, and spent more time investigating them, but did so at greater distances. We can only speculate about the degree to which free-ranging coyotes would devote the time required to overcome their caution regarding novel circumstances.

In our study, the scent stations did not appear to present as strong a stimulus to captive coyotes as the novel objects because coyotes spent more time investigating the objects, approached or investigated the objects with greater frequency, and displayed more approach-withdrawal behaviors toward the objects than to the scent stations. Because the scent capsules were placed in the pens about $1 \mathrm{~h}$ before the trials began, some coyotes may have detected the odor before encountering the scent station. This could have reduced novelty of the scent station. However, Windberg (1996) indicated that his coyotes did not direct their attention to olfactory cues until they were within $2 \mathrm{~m}$, which suggests that accommodation to the cues in our study was unlikely. Artificial scent stations used in coyote-abundance surveys (Linhart and Knowlton 1975; Roughton and Sweeny 1982) have a strong visual stimulus as well as an olfactory component. In the pens, the $1 \mathrm{~m}$ diameter scent station cut out of the grassalfalfa sod presented a visual contrast with the surroundings. Similar contrasts are potentially presented in field situations 
when scent stations are placed along roadsides or if differentcolored earth is sifted onto existing substrates. Coyotes may respond to either or both of these stimuli when approaching or avoiding a scent station. Griffith et al. (1981) suggested that visual cues may be important determinants of coyote responses to scent stations. Since Windberg (1996), using virtually no visual cues, reported that none of 38 coyotes showed neophobic behaviors toward the olfactory attractants he tested, the neophobic response of our coyotes to scent stations was probably associated more with visual cues than with olfactory ones. This agrees with Wells and Lehner's (1978) hypothesis that coyotes have a declining sensory ranking from visual to auditory to olfactory stimuli. Since Lehner et al. (1976) used odors assumed to be obnoxious and intended for use as repellents, we are inclined to discount their suggestion that coyotes have an initial neophobic response toward novel odors. Those authors did suggest, however, that coyotes are not likely to be born with an innate fear of particular odors, but learn to associate certain olfactory stimuli with aversive events which they encounter.

The degree of neophobia demonstrated by captive coyotes appears to be less than that reported for wild rats, because in general, the avoidance was not as persistent (Barnett 1958a, 1958b; Cowan 1976, 1977). Avoidance of novel objects by wild rats may be a product of selection resulting from methods used to control rat populations (Chitty 1954; Shorten 1954; Barnett 1963; Cowan 1976, 1977). Similarly, coyotes reared in captivity, although not domesticated, may not respond as strongly as or in exactly the same manner as wild coyotes subjected to depredation-control efforts or to other experiences with man. Because they have few negative experiences associated with investigating novel objects, captive coyotes may have less incentive to develop or exercise cautious or neophobic responses.

The variable behavior toward novel objects observed in our study could be due in part to differences in rearing conditions, individual differences in behavior, or dominance status (Summerlin and Wolfe 1971, 1973; Brown 1973; Bekoff 1977; Knight 1978). Stokes and Balph (1965) suggest that captive animals frequently live in stimulus-impoverished environments (ones with little diversity of stimuli) and hence may lack the wariness of their wild counterparts. Glickman and Sroges (1966) noted that captive coyotes (and carnivores in general) explore novel objects with little or no hesitation, and attributed such behavior to the food-seeking habits of these species that require immediate and fearless responses to a variety of forms. However, Burritt and Provenza (1997) indicated that lambs are less inclined to feed on novel foods in unfamiliar surroundings than in familiar ones. Although familiarity with the surroundings apparently influenced the responses of their animals, the responses were counter to those which we observed, suggesting that responses to novelty may differ between investigative and ingestive functions.

The probability of wild coyotes visiting (scoring at) scent stations is a function of both detecting the station and subsequently responding favorably to it. Factors that may influence whether or not coyotes detect scent stations include scent-station density, coyote density, home-range size, daily and seasonal activity patterns, movement patterns, prey abundance, coyote foraging behavior, weather, and habitat characteristics. Behavioral responses once a scent station is detected may be affected by the location of the scent station with respect to home areas (Lehner 1976), prior experience of the coyotes (Andelt et al. 1985), and variation among individual coyotes.

Previous studies have suggested that coyotes may be more attentive along the periphery or outside their home areas (Hibler 1977; Bowen and Cowan 1980). Scent station survey lines on roads that coyotes treat as territorial boundaries may elicit more visits than those passing through the middle of territories. Coyotes appear to use visual cues associated with topographic features, such as roads, as territorial boundaries (Wells and Bekoff 1981; Harris 1983; Knowlton et al. 1986). The degree to which coyotes utilize roads as travel routes, thereby enhancing the probability of encountering scent stations, varies with habitat (Hodges 1975). The dense brush lands on our study area probably caused greater use of roads by coyotes.

Because of small home areas and the large number of roads used as boundaries of home areas, there were few roads, and hence few scent stations, in the core portions of coyote home areas in our study. The higher proportion of roads acting as home-range boundaries and the behaviors associated with such boundaries, i.e., scent-marking and increased attentiveness (Camenzind 1978; Bowen and Cowan 1980; Wells and Bekoff 1981; Gese and Ruff 1997), may have resulted in greater scent station visitation rates along these roads. We are not implying that coyotes do not thoroughly explore the core areas of their home ranges, but as familiarity with a particular environment increases, habituation may replace attentiveness and exploration. If inattentive, a coyote might inadvertently and repeatedly bypass scent stations in a familiar environment without detecting or responding to the stimuli. Griffith (1976) reported that $12.1 \%$ of the coyotes in their study passed within $0.45-1.36 \mathrm{~m}$ of a scent station, they did so without scoring, and an additional $35.2 \%$ passed within $2.27-5.00 \mathrm{~m}$ without scoring.

Detection of an artificial scent station in a familiar environment may result in avoidance rather than approach and investigation. Griffith et al. (1981) presented evidence, based upon tracks in roads, that some coyotes actively avoid scent stations. In a previous report (Griffith 1976) he estimated that only $28.8 \%$ of the coyotes that came within $9.1 \mathrm{~m}$ of scent stations scored at them. The olfactory and (or) visual aspects of the dusted scent stations attract some coyotes, but it also seems likely that wary individuals might avoid the disturbed ground, at least initially. Coyotes may also be less attentive to mild novel stimuli inside their home ranges than outside (Hibler 1977). In our study, wild coyotes more frequently visited scent stations near the periphery of or outside their home areas until they became more familiar with the stations. Assuming that the number of telemetry locations within the same grid cell as scent stations is a reasonable index of coyote exposures to the stations, it appears that coyotes encountering scent stations along the periphery of their home areas are twice as likely to score (leave their tracks within the $1 \mathrm{~m}$ diameter circle) as those encountering scent stations in the interior of their home area, and when scent stations are encountered away from their home area (and are perhaps trespassing upon adjacent territories) the coyotes are 20 times more likely to score (Table 4). 
Previous experience with, or repeated presentation of, a stimulus can affect behavior during subsequent encounters (Andelt et al. 1985). The 2 coyotes in the field aspect of our study that visited scent stations within their home ranges had previously visited scent stations on the periphery of or outside their home areas (Table 4). Having previously investigated these stimuli and suffered no adverse consequences, they may have been more likely to approach and investigate them in a familiar environment. Conversely, it might be argued that repeated exposure may lead to habituation and eventual disinterest in investigating a stimulus.

The importance of understanding coyote behavioral responses to various stimuli lies in the premise that we can better tailor management and research techniques through a better understanding of coyote behaviors (Knowlton 1972; Lehner 1976). We conclude that responses of captive coyotes to novel objects and scent stations are dependent upon the coyotes' familiarity with them, as well as their familiarity with the area in which they encounter these stimuli. Coyotes showed greater caution toward, and avoidance of, novel objects and scent stations encountered in familiar environments than in unfamiliar environments. The results of our field study suggest that coyotes are more apt to visit scent stations encountered along the periphery of or outside their home ranges than inside. The degree to which this results from active avoidance of a novel stimulus in a familiar environment or failure to detect it is currently uncertain. The differential distribution of capture locations among trapped coyotes noted by Windberg and Knowlton (1990) and others suggests that very subtle cues may be involved. Implications with regard to potential biases associated with trapping animals, or the degree to which these concepts should be extended to other species (Conner et al. 1983), remain to be explored.

\section{Acknowledgments}

This study was conducted under the guidance and support of the Denver Wildlife Research Center (DWRC) of the Fish and Wildlife Service, U.S. Department of the Interior, under Work Unit DF-931.07. In 1986, DWRC was administratively transferred to The Animal and Plant Health Inspection Service of the U.S. Department of Agriculture and subsequently moved to Fort Collins, Colorado, and renamed the National Wildlife Research Center. We thank R. Burns, M. Collinge, R. Griffiths, R. Roughton, and W. Stephensen for their assistance during the pen studies. W. Stephensen also assisted in capturing coyotes for the field study. M. Collinge, R. Griffiths, R. Roughton, W. Wagner, and L. Windberg, as well as S. Bell, J. Grennier, B. Kelly, S. Linner, N. McDonald, J. Olson, J. Till, S. Whittemore, and A. Wywialowski, assisted in collecting telemetry and scent-station data. We appreciate permission from $\mathrm{C}$. Manges to use his properties as a study area, and acknowledge G. White, Los Alamos National Laboratory, for assistance with data analysis and computer graphics. R. Burns, E.M. Gese, J.R. Mason, W.C. Pitt, R. Sterner, and C. Stoddart reviewed various drafts of the manuscript. The U.S. Department of Energy, Office of Health and Environmental Research, provided support for C. Harris during the preparation of earlier drafts of the manuscript through contract No. DE-AC08-833NV10282 with EG \& G Energy Measurements, Inc.

\section{References}

Althoff, D.P. 1978. Social and spatial relationships of coyote families and neighboring coyotes. M.S. thesis, University of $\mathrm{Ne}$ braska, Lincoln.

Andelt, W.F., and Gipson, P.S. 1980. Toe-clipping coyotes for individual identification. J. Wildl. Manag. 44: 293-294.

Andelt, W.F., Harris, C.E., and Knowlton, F.F. 1985. Prior trap experience might bias coyote responses to scent stations. Southwest. Nat. 30: 317-318.

Baer, C.H., Severson, R.E., and Linhart, S.B. 1978. Live capture of coyotes from a helicopter using ketamine hydrochloride. J. Wildl. Manag. 42: 452-454.

Balph, D.F. 1968. Behavioral responses of unconfined Uinta ground squirrels to trapping. J. Wildl. Manag. 32: 778-794.

Barnett, S.A. 1958a. Experiments on 'neophobia' in wild and laboratory rats. Br. J. Psychol. 49: 195-201.

Barnett, S.A. 1958b. Exploratory behavior. Br. J. Psychol. 49: 289310.

Barnett, S.A. 1963. The rat: a study in behavior. Methuen and Co. Ltd., London.

Bekoff, M. 1977. Mammalian dispersal and the ontogeny of individual behavioral phenotypes. Am. Nat. 111: 715-732.

Bowen, W.D., and Cowan, I.M. 1980. Scent marking in coyotes. Can. J. Zool. 58: 473-480.

Brown, J.B. 1973. Behavioral correlates of rank in a captive litter of coyotes (Canis latrans). M.S. thesis, Purdue University, West Lafayette, Ind.

Burritt, E.A., and Provenza, F.D. 1997. Effect of an unfamiliar location on the consumption of novel and familiar foods by sheep. Appl. Anim. Behav. Sci. 54: 317-325.

Camenzind, F.J. 1978. Behavioral ecology of coyotes on the National Elk Refuge, Jackson, Wyoming. In Coyotes: biology, behavior, and management. Edited by M. Bekoff. Academic Press, New York. pp. 267-294.

Chitty, D. 1954. The study of the brown rat and its control by poison. In Control of rats and mice. Edited by D. Chitty. Clarendon Press, Oxford. pp. 160-305.

Conner, M.C., Labisky, R.F., and Progulske, D.R., Jr. 1983. Scentstation indices as measures of population abundance for bobcats, raccoons, gray foxes, and opossums. Wildl. Soc. Bull. 11: 146152.

Cornely, J.E. 1979. Anesthesia of coyotes with ketamine hydrochloride and xylazine. J. Wildl. Manag. 43: 577-579.

Cowan, P.E. 1976. The new object reaction of Rattus rattus L.: the relative importance of various cues. Behav. Biol. 16: 31-44.

Cowan, P.E. 1977. Neophobia and neophilia: new-object and newplace reactions of three Rattus species. J. Comp. Physiol. Psychol. 91: $63-71$.

Errington, P.L. 1946. Predation and vertebrate populations. Q. Rev. Biol. 21: 144-177, 221-245.

Errington, P.L. 1967. Of predation and life. Iowa State University Press, Ames.

Gese, E.M., and Ruff, R.L. 1997. Scent-marking by coyotes, Canis latrans: the influence of social and ecological factors. Anim. Behav. 54: 1155-1166.

Glickman, S.E., and Sroges, R.W. 1966. Curiosity in zoo animals. Behaviour, 26: 151-188.

Gould, F.W. 1975. Texas plants: a checklist and ecological summary. Tex. Agric. Exp. Stn. Misc. Publ. No. 585. 
Griffith, B., Wight, H.M., Overton, W.S., and Meslow, E.C. 1981. Seasonal properties of the coyote scent station index. In Proceedings of a Symposium on Census and Inventory Methods for Populations and Habitats, Banff, Alberta, 10 April 1980. Edited by F.L. Miller and A. Gunn. Contribution No. 217, Forest, Wildlife and Range Experiment Station, University of Idaho, Moscow. pp. 197-220.

Griffith, D.B. 1976. Seasonal properties of the coyote scent station index. M.S. thesis, Oregon State University, Corvallis.

Harris, C.E. 1983. Differential behavior of coyotes with regard to home range limits. Ph.D. dissertation, Utah State University, Logan.

Heezen, K.L., and Tester, J.R. 1967. Evaluation of radio-tracking by triangulation with special reference to deer movements. J. Wildl. Manag. 31: 124-141.

Hibler, S.J. 1977. Coyote movement patterns with emphasis on home range characteristics. M.S. thesis, Utah State University, Logan.

Hodges, J.I. 1975. The statistical properties of the scent-station method for indexing coyote abundance. Final report to U.S. Fish and Wildlife Service, Contract No. 14-16-008-1123, Oregon State University, Corvallis.

Hollander, M., and Wolfe, D.A. 1973. Nonparametric statistical methods. John Wiley and Sons, New York.

Kitchen, A.M., Gese, E.M., and Schauster, E.R. 2000. Long-term spatial stability of coyote (Canis latrans) home ranges in southeastern Colorado. Can. J. Zool. 78: 458-464.

Knight, S.W. 1978. Dominance hierarchies of captive coyote litters. M.S. thesis, Utah State University, Logan.

Knowlton, F.F. 1972. Preliminary interpretations of coyote population mechanics with some management implications. J. Wildl. Manag. 36: 369-382.

Knowlton, F.F. 1995. Radio telemetry as a wildlife research tool. In The development of international principles and practices of wildlife research and management: Asian and American approaches. Edited by S.H. Berwick and V.B. Saharia. Oxford University Press, Delhi, India. pp. 81-106.

Knowlton, F.F., and Whittemore, S.L. 2001. Pulp cavity - tooth width ratios from known-age and wild-caught coyotes determined by radiography. Wildl. Soc. Bull. 29: 239-244.

Knowlton, F.F., Windberg, L.A., and Wahlgren, C.E. 1986. Coyote vulnerability to several management techniques. In Proceedings of the 7th Great Plains Animal Damage Control Workshop, San Antonio, Texas, 3-5 December 1985. Edited by D.B. Fagre. Texas A\&M University, College Station. pp. 165-176.

Kolz, A.L., Corner, G.W., and Johnson, R.E. 1973. A multiple use wildlife transmitter. Spec. Sci. Rep. Wildlife No. 163, U.S. Fish and Wildlife Service Denver Wildlife Research Center, Denver, Colo.

Laundre, J.W., and Keller, B.L. 1981. Home-range use by coyotes in Idaho. Anim. Behav. 29: 449-461.

Laundre, J.W., and Keller, B.L. 1984. Home range size of coyotes: a critical review. J. Wildl. Manag. 48: 127-139.

Lehner, P.N. 1976. Coyote behavior: implications for management. Wildl. Soc. Bull. 4: 120-126.

Lehner, P.N., Krumm, R., and Cringan, A.T. 1976. Tests for olfactory repellents for coyotes and dogs. J. Wildl. Manag. 40: 145-150.

Linhart, S.B., and Knowlton, F.F. 1967. Determining age of coyotes by tooth cementum layers. J. Wildl. Manag. 31: 362-365.

Linhart, S.B., and Knowlton, F.F. 1975. Determining the relative abundance of coyotes by scent stations. Wildl. Soc. Bull. 3: $119-124$.

Litvaitis, J.A. 1978. Movements and habitat use of coyotes on the Wichita Mountains National Wildlife Refuge. M.S. thesis, Oklahoma State University, Stillwater.

Mech, L.D. 1977. Productivity and population trends of wolves in northern Minnesota. J. Mammal. 58: 559-574.

Metzgar, L.H. 1967. An experimental comparison of screech owl predation on resident and transient white-footed mice (Peromyscus leucopus). J. Mammal. 48: 387-391.

Nie, N.H., Hull, C.H., Jenkins, J.G., Steinbrenner, R., and Bent, D.H. 1975. Statistical package for the social sciences. McGraw Hill, Inc., New York.

Rongstad, O.J., and Tester, J.R. 1969. Movements and habitat use of white-tailed deer in Minnesota. J. Wildl. Manag. 33: 366-379.

Roughton, R.D. 1982. A synthetic alternative to fermented egg as a canid attractant. J. Wildl. Manag. 46: 230-234.

Roughton, R.D., and Sweeny, M.W. 1982. Refinements in scentstation methodology for assessing trends in carnivore populations. J. Wildl. Manag. 46: 217-229.

Ruggiero, L.F., Cheney, C.D., and Knowlton, F.F. 1979. Interacting prey characteristic effects on kestrel predatory behavior. Am. Nat. 113: 749-795.

Schneirla, T.C. 1965. Aspects of stimulation and organization in approach withdrawal processes underlying vertebrate behavioral development. In Advances in the study of behavior. Edited by D.S. Lehrman, R.A. Hinde, and E. Shaw. Academic Press, New York. pp. 1-74.

Sheppe, W. 1966. Exploration by the deer mouse, Peromyscus leucopus. Am. Midl. Nat. 76: 257-276.

Shorten, M. 1954. The reaction of the brown rat towards changes in its environment. In Control of rats and mice. Vol. II. Edited by D. Chitty. Clarendon Press, Oxford. pp. 307-334.

Stokes, A.W., and Balph, D.F. 1965. The relation of animal behavior to wildlife management. Trans. N. Am. Wildl. Nat. Resour. Conf. 13: 401-410.

Summerlin, C.T., and Wolfe, J.L. 1971. Social influence on exploratory behavior in the cotton rat, Sigmodon hispidus. Commun. Behav. Biol. 6: 105-109.

Summerlin, C.T., and Wolfe, J.L. 1973. Social influence on trap response of the cotton rat Sigmodon hispidus. Ecology, 54: 11561159 .

U.S. Department of Commerce. 1982. Monthly normals of temperature, precipitation, and heating and cooling days 1951-80: climatology of the U.S. No. 81 (Texas). U.S. Department of Commerce, Washington, D.C.

Wells, M.C., and Bekoff, M. 1981. An observational study of scentmarking in coyotes, Canis latrans. Anim. Behav. 29: 322-350.

Wells, M.C., and Lehner, P.N. 1978. The relative importance of the distance senses in coyote behaviour. Anim. Behav. 26: 251-258.

Windberg, L.A. 1996. Coyote responses to visual and olfactory stimuli related to familiarity with an area. Can. J. Zool. 74: 2248-2253.

Windberg, L.A., and Knowlton, F.F. 1988. Management implications of coyote spacing patterns in southern Texas. J. Wildl. Manag. 52: 632-640.

Windberg, L.A., and Knowlton, F.F. 1990. Relative vulnerability of coyotes to some capture procedures. Wildl. Soc. Bull. 18: 282290.

Windberg, L.A., Knowlton, F.F., Ebbert, S.W., and Kelly, B.T. 1997. Differential capture vulnerability of coyotes relative to range boundaries. J. Wildl. Res. 2: 205-209.

Woodruff, R.A., and Keller, B.L. 1982. Dispersal, daily activity, and home range of coyotes in south-eastern Idaho. Northwest Sci. 56: 199-207.

Zar, J.H. 1996. Biostatistical analysis. 3rd ed. Prentice Hall Inc., Upper Saddle River, N.J. 
Copyright $\odot 2003$ EBSCO Publishing 